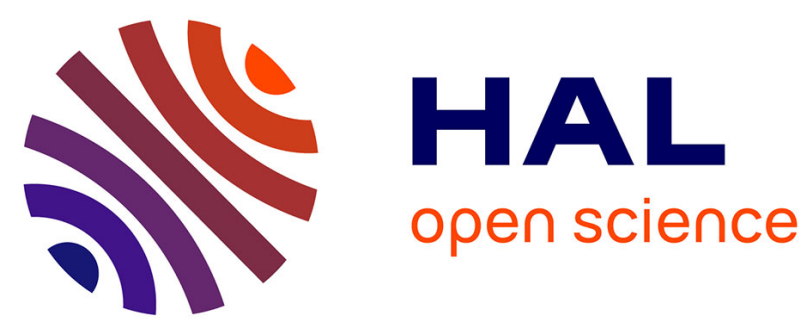

\title{
ALUMINIUM-LITHIUM-COPPER-MAGNESIUM- ZIRCONIUM ALLOYS WITH HIGH STRENGTH AND HIGH TOUGHNESS - SOLVING THE PERCEIVED DICHOTOMY
}

\author{
W. Miller, J. White, M. Reynolds, D. Mcdarmaid, G. Starr
}

\section{To cite this version:}

W. Miller, J. White, M. Reynolds, D. Mcdarmaid, G. Starr. ALUMINIUM-LITHIUM-COPPERMAGNESIUM-ZIRCONIUM ALLOYS WITH HIGH STRENGTH AND HIGH TOUGHNESS SOLVING THE PERCEIVED DICHOTOMY. Journal de Physique Colloques, 1987, 48 (C3), pp.C3151-C3-162. 10.1051/jphyscol:1987318 . jpa-00226548

HAL Id: jpa-00226548 https://hal.science/jpa-00226548

Submitted on 1 Jan 1987

HAL is a multi-disciplinary open access archive for the deposit and dissemination of scientific research documents, whether they are published or not. The documents may come from teaching and research institutions in France or abroad, or from public or private research centers.
L'archive ouverte pluridisciplinaire HAL, est destinée au dépôt et à la diffusion de documents scientifiques de niveau recherche, publiés ou non, émanant des établissements d'enseignement et de recherche français ou étrangers, des laboratoires publics ou privés. 


\title{
ALUMINIUM-LITHIUM-COPPER-MAGNESIUM-ZIRCONIUM ALLOYS WITH HIGH STRENGTH AND HIGH TOUGHNESS - SOLVING THE PERCEIVED DICHOTOMY
}

\author{
W.S. MILLER, J. WHITE, M.A. REYNOLDS, D.S. MCDARMAID* and \\ G.M. STARR*
}

Alcan International Ltd., Southam road, Banbury, GB-Oxon OX16 7SP, Great-Britain

* The Royal Aircraft Establishment, Materials and structures

Department, GB-Farnborough GU16 6TD, Hampshire, Great-Britain

\begin{abstract}
Throughout the past decade extensive research and development has been carried out on aluminium-lithium base alloys because of the attractive combination of laver density and higher modulus that can be achieved in this system compared with "conventional" aluminium alloys. Much of this effort has been directed at understanding and overcoming their "Achilles heel" of low ductility and poor fracture toughness (particularly for crack planes perpendicular to the short transverse direction). This study reviews the metallurgical features which affect ductility and damage tolerance in the 8090 and 8091 alloys developed at Alcan and the Royal Aircraft Establishment. The paper shows that control of these metallurgical features can be used to markedly improve these properties. Three examples will be given.

In the first case the production of material with a high damage tolerance will be discussed. It will be shown that by control of grain structure and ageing practice, 8090 sheet with a plane stress fracture toughness $(\mathrm{Kc})$ of $>130$ $\mathrm{MPa} / \sqrt[\mathrm{m}]{\mathrm{m}}$ can be achieved at simflar strength levels to 2024-T3 sheet. There is also a decrease in fatigue crack growth rate. This results in sheet with an overall damage tolerance capability comparable with that of 2024-T3.

The other examples concern the processing of 8090 and 8091 plate to meet medium and high strength airframe requirements respectively. 8090 plate $(<100$ $\mathrm{mm}$ thick) can achieve the property requirements of 7010-T7651, with short transverse ductilities in excess of $3 \%$ and short transverse fracture toughness of $>18 \mathrm{MPa} / \mathrm{m}$. This is accomplished by controlled thermomechanical treatment. Similar treatments applied to the 8091 alloy result in a material competitive with 7150-T651 for specific apnlications (e.g.upper wing skins, where short transverse performance is sacrificed in favour of in-plane properties).
\end{abstract}

\section{INTRODUCTION}

Throughout the past decade extensive research and development has been carried out on aluminium-lithium based alloys because of the attractive combination of lower density and higher modulus that can be achieved in this system compared with "conventional" aluminium alloys(1-3). Much of this effort has been directed at understanding and improving the fracture toughness of the alloy (particularly for crack planes orientated perpendicular to the short transverse direction)(4-6). This study reviews the key metallurgical features which influence strength, deformation behaviour and fracture characteristics of the 8090 and 8091 alloys developed at Alcan and the Royal Aicraft Establishment (7). Both alloys are based on the Al-Li-Cu-Mg-Zr system. This paper shows how control of these metallurgical features can be used to markedly improve strength and fracture toughness, either individually or in combination. The principles involved will be illustrated by highlighting the development of 8090 sheet with a high damage tolerant capability and the development of 8090 and 8091 plate with combined strength and fracture toughness requirements. 
In the case of damage tolerant sheet a prerequisite is that it should have a good resistance to fatigue crack growth coupled with a high plane stress fracture toughness. Clearly an aluminium-lithium base alloy with these features and an overall performance equivalent to $2024-\mathrm{T} 3$ would be extremely attractive to airframe manufactures especially when accompanied with a $10 \%$ reduction in density.

8090, in plate form, was originally designed as a medium strength replacement for alloys such as 2014-T651. At Aluminium-Lithium 3 Peel , Evans and McDarmaid (8) put forward the proposal for a second generation alloy to replace the higher strength 7010/7050-T7651 alloys. The objective of this part of the paper is to show how control of the microstructure both within the matrix (to optimize strength) and at grain boundaries (to optimize fracture toughness) can be used to achieve this goal. This is accomplished by final thermomechanical treatment (FTMT) in 8090 without the need to change the alloy chemistry.Similar FTMT' $s$ have also been applied to the higher strength 8091 alloy in an attempt to develop an alloy competitive with 7150-T651. The full details of the microstructural consequences of the FTMT's used in this work are discussed in detail in the paper by white et al(9).

\section{METALLURGICAL VARIABLES INFLUENCING STRENGTH AND TOUGENESS}

It is not the intention of this paper to discuss fully the metallurgical variables influencing strength and toughness since these have been detailed previously (1-3). Instead the key factors will be briefly discussed.

\section{a. Strength}

In the case of $\mathrm{Al}-\mathrm{Li}-\mathrm{Cu}-\mathrm{Mg}-\mathrm{Zr}$ alloys the various contributions to their strength have been discussed elsewhere $(10,11)$. A key feature found was the importance of sub-structure in developing high strength, hence recrystallized structures will not achieve as high a strength as unrecrystallized structures. Additionally it was shown that the contributions from $\delta^{\prime}$ and $\mathrm{S}^{\prime} / \mathrm{T}$, should be maximized. Since $\delta^{\prime}$ nucleates homogeneously and $S^{\prime}$ heterogeneously this is usually accomplished by stretching the alloy prior to ageing. This enables the copper containing age hardening phases to nucleate throughout the matrix $(12,13)$.

\section{b. Deformation.}

It is well established that deformation in $\mathrm{Al}-\mathrm{Li}-\mathrm{Cu}-\mathrm{Mg}$ alloys is concentrated along slip planes due to the coherent nature of $\delta^{\prime}(14,15)$. Planar slip gives rise to siress concentrations at grain boundaries, which in turn open up grain boundary cracks and induce failure. Planar siip effects can be minimized by the addition of zirconium which both reduces slip line length (by refinement of grain size) and introduces sub-grain boundaries that present barriers to dislocation movement $(6)$. The presence of the $S^{\prime}$ precipitate also modifies deformation mode by promoting cross-slip (12). Consequently planar slip is most marked in underaged tempers at which stage the $S^{\prime}$ phase has not grown to a sufficient size to effectively encourage cross-slip.

\section{c. Fracture}

Fracture in aluminium lithium alloys appears to be according to the following mechanism (4). Failure is predominantly along,grain boundaries parallel to the rolling plane, and connected to boundaries on adjacent planes by short lengths of more ductile failure along intersecting boundaries and shea bands. The lower ductility and fracture toughness observed in short transverse orientations can thus be explained since the weak boundaries are orientated perpendicular to the applied stress and are more susceptible to fracture. In addition any constituent particles (iron-rich intermetallics or grain boundary precipitates) are also aligned in the plane and further reduce load bearing capacity due to void formation (16).

The propensity for grain boundary failure in these alloys has been attributed to the following mechanisms, planar slip (15), strain localisation in precipitate free zones $(5,17)$, grain boundary embrittlement due to precipitation at grain boundaries (18) and impurity segregation effects(19). 
In summary these observations indicate that precipitation within the matrix should be maximised for strength and reducing planar slip affects and that precipitation at grain boundaries should be minimised to maintain a satifactory fracture toughness. Clearly as both reactions occur simultaneously processing and heat treatment practices must be carefully manipulated to obtain the desired balance of properties.

\section{RESULTS AND DISCUSSION}

\section{A. DAMAGE TOLERANT SHEET}

It has already been reported that the fatigue crack growth resistance of 8090 is at least five times better than that of 'conventional' alloys and that modifications to the microstructure of 8090 (i.e. from unrecrystallized to a recrystallized grain structure), can give a further improvement (20). This improvement can be increased still further by using the alloy in a lightly aged condition rather than either naturally aged or peak aged(21). These improvements arise because of the propagation of fatigue cracks transgranularly along coarse slip planes. The development of these slip planes is affected by the degree of planar slip, which in turn is controlled by the matrix

microstructure, Figure 1. The tortuosity of the crack path will be affected by grain structure and texture. Thus fatigue crack growth rate is characterised in terms of the effect of grain structure and ageing parameters.

The objective of this excercise is to determine the effect of grain structure and ageing practice on the plane stress fracture toughness of 8090 sheet. Material was manufactured through a commercial route using various combinations of processing parameters. Grain structure control of sheet is attained by controlling the alloy's zirconium content, the size and distribution of overaged precipitates, the degree of cold work and the rate of heating to the recrystalization (solution treatment) temperature(22). It is thus possible to produce sheet with a variety of grain structures which range from

unrecrystallized to fully recrystallized with an equiaxed structure (Figure 2 ).

Plane stress fracture toughness tests were carried out using centre notched panels to ASTM (23) and GARTEUR requirements (24). The plane stress fracture toughness values $\mathrm{Kao}$ and $\mathrm{Kc}$ were calculated using the initial crack length and instantaneous crack length at maximum load respectively .Crack resistance curves ( $\mathrm{R}$-curves) were determined to characterize the fracture resistance. Comparative tests were carried out on 2024-T3 and 2014-T6 sheet obtained from commercial suppliers.

Typical. R-curves for the grain structure variables produced, Figure 3 , show that the recrystallized sheets have a higher resistance to fracture than the unrecrystallized sheets. In addition the finer the recrystallized grain size the higher is the resistance to fracture. These observations arise because the plane stress fracture toughness is dependent on the amount of deformation occurring in the plastic zone. Under these condition of 'strain control', a fine grain recrystallized structure is required to generate greater strains tó failure in the plastic zone compared with coarse or unrecrystallised structures. 2024-T3 tested identical conditions has a fracture toughness (Kc) of $160 \mathrm{MPa} \sqrt{\mathrm{m}}$ but the data was invalid due to excess plasticity

To fulfill the validity criterion that the net stress at Kc should be less than the $0.2 \%$ proof stress, panel widths should not be less than $400 \mathrm{~mm}$ - As increasing the panel width also increases the calculated Kao and Kc (see Figure 4) all the comparative tests were carried out on either $400 \mathrm{~mm}$ or $500 \mathrm{~mm}$ wide panels. However Figure 5 shows that 8090 sheet with a fine recrystallised grain structure has a Kc of $174 \mathrm{MPa} \sqrt{\mathrm{m}}$ and a Kao of $118 \mathrm{MPa} \sqrt{\mathrm{m}}$ (panel width $760 \mathrm{~mm}$ ), which compares with values of $203 \mathrm{MPa} \sqrt{\mathrm{m}}$ and $110 \mathrm{MPa} \sqrt{\mathrm{m}}$ repectively for 2024-T3.

Figure 5 shows the variation of fracture toughness with $0.2 \%$ proof stress. The fracture toughness for all the grain structures investigated decreases with increasing proof stress. In the $\mathrm{L}-\mathrm{T}$ orientation the Kao and Kc of the fine grain recrystallized sheet are $25 \mathrm{MPa} \sqrt{\mathrm{m}}$ and $60 \mathrm{MPa} \sqrt{\mathrm{m}}$ higher respectively than unrecrystalized sheet.It is worth noting that the fracture toughness of unrecystallised 8090 sheet is comparable with that of 2014-T6 sheet at an equivalent strength level. The effect of proof strength on the 
fracture toughness of fine grain recrystallized 8090 sheet is illustrated in Figure 6 which shows that the fracture toughness is comparatively stable over the practical range of proof strengths.

To date only a limited number of tests have been carried out in the $T-L$ orientation, Table 1 . These show the same trends as the L-T orientation although at slightly lower overall toughness (a similar decrease is found for 2024-T3).

The determined values of toughness coupled with fatigue crack growth resistance (discussed earlier) shows that by controlling grain structure of 8090 sheet, to produce a fine recrystallised structure, the airframe constructers needs for low density damage tolerant sheet (equivalent to 2024-T3) can be met.

\section{B. HIGH STRENGTH AND HIGH TOUGHNESS (8090 PLATE)}

The first aspects covered are ageing time and ageing temperature. It is well established in other aluminium alloy systems that reducing ageing temperature refines matrix precipitation and reduces both grain boundary precipitate size and the associated precipitate free zone (PFZ) width. The former should increase strength and the latter should improve fracture toughness.

Figure 7 shows the influence of ageing temperature on the T-L orientation strength and toughness of $809025 \mathrm{~mm}$ plate.The fracture toughness/strength relationship is improved as the ageing temperature is decreased from $190 \mathrm{C}$ to $135 \mathrm{C}$ associated with the expected reduction in PFZ width. The microstructural and property benefits of using low temperature ageing treatments, however, must be balanced by practical and commercial considerations. Low ageing temperatures require long ageing times to reach the required strength levels (e.g.100+ hours at $150 \mathrm{C}$ ), such times require increased investment in ageing ovens with a resultant cost penalty on the finished product. The use of lower ageing temperatures thus has a practical limit and further improvements must be sought by other means. One method is to increase the level of cold work before ageing. It has already been demonstrated that stretching $2-3 \%$ is necessary to ensure the precipitation of $\mathrm{S}^{\prime}\left(\mathrm{Al}_{2} \mathrm{CuMg}\right)$ phase in the matrix thus increasing strength (11). The stretch also reduces the volume fraction of grain boundary precipitates and hence PFZ width. The effect of higher levels of stretch on microstructure is detailed elsewhere (9). Figure 8 shows the effect of stretching up to $8 \%$ and ageing at $170 \mathrm{C}$ on the $\mathrm{T}-\mathrm{L}$ orientation strengthtoughness relationship of the same $809025 \mathrm{~mm}$ plate considered earlier. As stretch is increased the fracture toughness increases for a constant value of the $0.2 \%$ proof stress. This improvement is not due to any significant modification of grain boundary microstructure resulting from the increase in stretch. Instead it is largely attributable to the fact that to achieve the same level of $0.2 \%$ proof strength at the higher levels of stretch a shorter ageing time can be used. This results in a more underaged temper and hence higher fracture toughness.It is also probabie that the increased stretch affects the precipitation of $S^{\prime}$ and also introduces dislocation tangles into the matrix. Both of these will reduce planar slip and thus the likelyhood of stress concentration build up at grain boundaries.

The obvious next stage is to combine lower ageing temperatures with an increase in the level of stretch prior to ageing. The result of this is shown in Figure 9 in which the strength and fracture coughness of plate stretched $6 \%$ and aged for $24 \mathrm{~h}$ at $170 \mathrm{C}$ is compared vith that of the same plate stretched $2 \%$ and aged for $16 \mathrm{~h}$ at $190 \mathrm{C}$. The material aged using the modified FTMT shows both improved strength and fracture toughness.

Such FTMT's are now being used on a commercial scale and Table 2 compares the results with the minimum property requirements of 7010-57651. Clearly the original target set by Peel et al( 8 ) has been met.

\section{ULTRA-HIGH STRENGTH PLATE}

In the paper of Peel et al (8) the possibility of developing a high strength aluminium-lithium alloy competitive with 7150-T651 plate was also proposed. This goal can be achieved by application of the above FTMT's to the higher strength 8091 alloy. Since for many applications of $7150-T 651$ through plane properties are not critical (e.g. upper wing skins) effort in this area has been concentrated on thin plate $(<25 \mathrm{~mm})$. Figure 10 compares the 
microstructure of 8091 given a $7 \%$ stretch and aged $32 \mathrm{~h}$ at $170 \mathrm{C}$ with that of the same alloy stretched $2 \%$ and aged $16 \mathrm{~h}$ at $190 \mathrm{C}$. The high stretched plate has a much finer PFZ, reduced amount of grain boundary precipitation and a more uniform matrix $S^{\prime}$ distribution. Figure 11 shows the strength and fracture toughness of $809112.5 \mathrm{~mm}$ plate given the above FTMT. Comparison with 7150-T651 requirements $(0.2 \%$ proof stress $=525 \mathrm{MPa}, \mathrm{T}$ L fracture toughness $=22 \mathrm{MPa} \sqrt{\mathrm{m}}$ indicate that the goal set by Peel et al( $8 \overline{)}$ is close to being met.

\section{CONCLUSIONS}

1. By control of grain structure and ageing practice 8090 alloy can be processed into recystaliised sheet with fracture toughness equivalent to 2024-T3.

2. Lowering the ageing temperature improves the strength- toughness relationship in 8090 plate by control of the grain boundary structure.

3. Increasing the level of stretch from $2 \%$ to $8 \%$ improves the strengthtoughness relationship in 8090 plate.

4. Combinations of low temperature ageing and high stretch levels enables the properties of 8090 plate to be competitive with 7010-T7651 alloy.

5 . By using similar procedures 8091 plate can be made competitive with 7150-T651 alloy.

\section{ACINOWLEDGEMENT}

The authors wish to thank their colleagues at Alcan and RAE for their assistance in the preparation of this paper. The paper is published with the permission of Alcan International and the Procurement Executive, Ministry of Defence.

\section{REFERENCES}

1. Aluminium-Lithium Alloys. Proc 1st. Int. Aluminium-Lithium Conference. Stone Mountain, Georgia. Ed. T.H.Sanders ; E.A.Starke. Pub Met. Soc. AIME 1981

2. Aluminium-Li thium Alloys 2. Proc.2nd. Int. Aluminium Li thium Conference Monterey CA. Ed. T.H.Sanders ; E.A.Starke . Pub. Met. Soc. AIME 1984.

3. Aluminium Lithium Alloys 3. Proc.3rd. Int. Aluminium Lithium Conference oxford UK.Ed. C.Baker,P.J.Gregson, S.J.Harris and C.J.Pee1. Pub.Institute of Met. 1985.

4. W.S.Miller,M.P.Thomas,D.J.Lloyd and D.Creber Mat.Sci.Tech.Dec 1986 Vol 2 p. 1210 :

5. A.K.Vasudevan, E.A.Ludwiczak,S.F.Bauman, P.R.Howell, R.D.Doherty and M.M.Kersker ibid. p1205.

6. T.H.Sanders. Final Report Contract N62269-76-C-0271 NADC Washington DC 1979.

7. M.A.Reynolds, A.Gray,E.Creed,R.M.Jordan and A.P.Titchener in ref 3 p57

8. C.J.Peel,B.Evans and D.S.McDarmaid in ref $3 \mathrm{p} 26$.

9. J.White, and W.S.Miller This conference

10. D.J.Lloyd ICSMA7 Montreal 1986. Ed. H.J.McQueen, J.P.Bailon, J.I.Dickson J.J.Jonas and M.G.Akben Vol 3 p1745 Pub. Pergamon Press 1986.

11. W.S.Miller, J. White and D.J.Lloyd. Proc Int. Conf on Aluminium Alloys Charlot tsville VA. Ed. T.H. Sanders and E.A.Starke, vol 3, p1799 Pub. EMAS 1986.

12. P.J.Gregson and H.M.Flower Acta Met 331985 p527.

13. M.Ahmad and T.Ericsson in ref $3 \mathrm{p} 509$.

14. T.H.Sanders, E.A.Ludwiczak and R.R. Sawtell Mat.Sci.Eng. 431980 p243.

15. T.H.Sanders and E.A.Starke Acta Met 301982 p927.

16. N.J.Owen,D.J.Field and E.P.Butler in ref $3 \mathrm{p} 576$.

17. F.S.Lin, S.B.Chakrabortty and E.A.Starke Met. Trans. 13 A 1982 p401.

18. S. Suresh and A.K. Vasudevan in ref 3 p595.

19. A.K. Vasudevan,A.C.Miller and M.M.Kersker in ref 2 p 181.

20. C.J.Peel, Paper presented at WESTTEC 1987

21. K.Dinsdale, S.J.harris and B.Noble. Prog. Rep. No. 2 for MoD contract 2024/072/HR/Mat 1982.

22. I.G.Palmer,W.S.Miller,D.J.Lloyd and M.J.Bull in ref 3 p565

23. ASTM E561-81 R-curve determination.

24. C. Wheeler,J.Eastabrook, D. Rooke, K. Schwalbe, W. Setz,A.deKonig RAE Technical

Report 81142/GARTEUR/TP-04 November 1981. 
TABLE 1

The Effect of Microstructure on the Plane Stress Fracture Toughness of 8090 Sheet T-L Orientation,

\begin{tabular}{|c|c|c|c|c|c|c|c|}
\hline \multirow{2}{*}{$\begin{array}{l}\text { Grain } \\
\text { Structure }\end{array}$} & \multirow{2}{*}{$\begin{array}{l}\text { Sheet } \\
\text { Thickness }\end{array}$} & \multirow{2}{*}{$\begin{array}{l}\text { Ageing } \\
\text { Treatment }\end{array}$} & \multirow{2}{*}{$\begin{array}{l}\text { Panel } \\
\text { Width } \\
\mathrm{mm}\end{array}$} & \multicolumn{2}{|c|}{ Tensile Date } & \multicolumn{2}{|c|}{$\begin{array}{l}\text { Fracture } \\
\text { Toughness }\end{array}$} \\
\hline & & & & $\begin{array}{l}0.2 \% \mathrm{PS} \\
\mathrm{MPa}\end{array}$ & $\begin{array}{l}\text { UTS } \\
\mathrm{MPa}\end{array}$ & $\begin{array}{l}\mathrm{x}_{\mathrm{ao}} \\
\mathrm{MPa} / \mathrm{m}\end{array}$ & $\frac{\mathrm{x}_{\mathrm{c}}}{\mathrm{MPa} / \mathrm{m}}$ \\
\hline $\begin{array}{l}\text { Fine Grain } \\
\text { Recrystallised }\end{array}$ & $\begin{array}{l}1.54 \\
1.54\end{array}$ & $\begin{array}{l}8 \mathrm{~h} \text { \& } 150^{\circ} \mathrm{C} \\
24 \mathrm{~h} \text { \& } 150^{\circ} \mathrm{C}\end{array}$ & $\begin{array}{l}500 \\
500\end{array}$ & $\begin{array}{l}315 \\
323\end{array}$ & $\begin{array}{l}430 \\
450\end{array}$ & $\begin{array}{l}89.4 \\
82.4\end{array}$ & $\begin{array}{l}123.0 \\
143.0\end{array}$ \\
\hline $\begin{array}{l}\text { Laminar } \\
\text { Recrysta11ised }\end{array}$ & $\begin{array}{l}1.50 \\
1.50 \\
1.60 \\
1.60\end{array}$ & $\begin{array}{l}8 \mathrm{~h} @ 150^{\circ} \mathrm{C} \\
8 \mathrm{~h} @ 150^{\circ} \mathrm{C} \\
24 \mathrm{~h} \text { @ } 150^{\circ} \mathrm{C} \\
24 \mathrm{~h} @ 150^{\circ} \mathrm{C}\end{array}$ & $\begin{array}{l}400 \\
400 \\
400 \\
400\end{array}$ & $\begin{array}{l}329 \\
329 \\
317 \\
317\end{array}$ & $\begin{array}{l}429 \\
429 \\
422 \\
422\end{array}$ & $\begin{array}{l}68.0 \\
73.0 \\
72.0 \\
68.0\end{array}$ & $\begin{array}{r}90.0 \\
105.0 \\
95.0 \\
98.0\end{array}$ \\
\hline 2024-T3 Clad & $1.6 \mathrm{~mm}$ & - & 500 & 300 & 452 & 92.8 & $182.5 *$ \\
\hline
\end{tabular}

* Invalid

TABLE 2

Comparison of the Mechanical Properties of a Commercial 8090 Plate Given a High Stretch and Low Temperature Ageing Practice with Minimum Requirements for 7010-T7651 P1ate

\begin{tabular}{|c|c|c|c|}
\hline Material Property & Test Direction & 8090 A1loy & $7010-\mathrm{T} 7651$ \\
\hline $0.2 \% \mathrm{PS}(\mathrm{MPa})$ & $\begin{array}{l}\mathrm{L} \\
\mathrm{T} \\
\mathrm{S}-\mathrm{T}\end{array}$ & $\begin{array}{l}498 \\
470 \\
390\end{array}$ & $\begin{array}{l}446 \\
446 \\
404\end{array}$ \\
\hline UTS (MPa) & $\begin{array}{l}L \\
T \\
S-T\end{array}$ & $\begin{array}{l}524 \\
519 \\
486\end{array}$ & $\begin{array}{l}515 \\
515 \\
487\end{array}$ \\
\hline E1 $(\%)$ & $\begin{array}{l}\mathrm{L} \\
\mathrm{T} \\
\mathrm{S}-\mathrm{T}\end{array}$ & $\begin{array}{l}6.2 \% \\
5.7 \% \\
3.2 \%\end{array}$ & $\begin{array}{c}8 \% \\
6 \% \\
2.5 \%\end{array}$ \\
\hline $\begin{array}{l}\text { Fracture Toughness } \\
\text { MPa/m }\end{array}$ & $\begin{array}{l}\mathrm{L}-\mathrm{T} \\
\mathrm{T}-\mathrm{I} \\
\mathrm{ST}-\mathrm{L}\end{array}$ & $\begin{array}{l}34 \\
28.5 \\
19.5\end{array}$ & $\begin{array}{l}25.0 \\
24.0 \\
18.0\end{array}$ \\
\hline
\end{tabular}




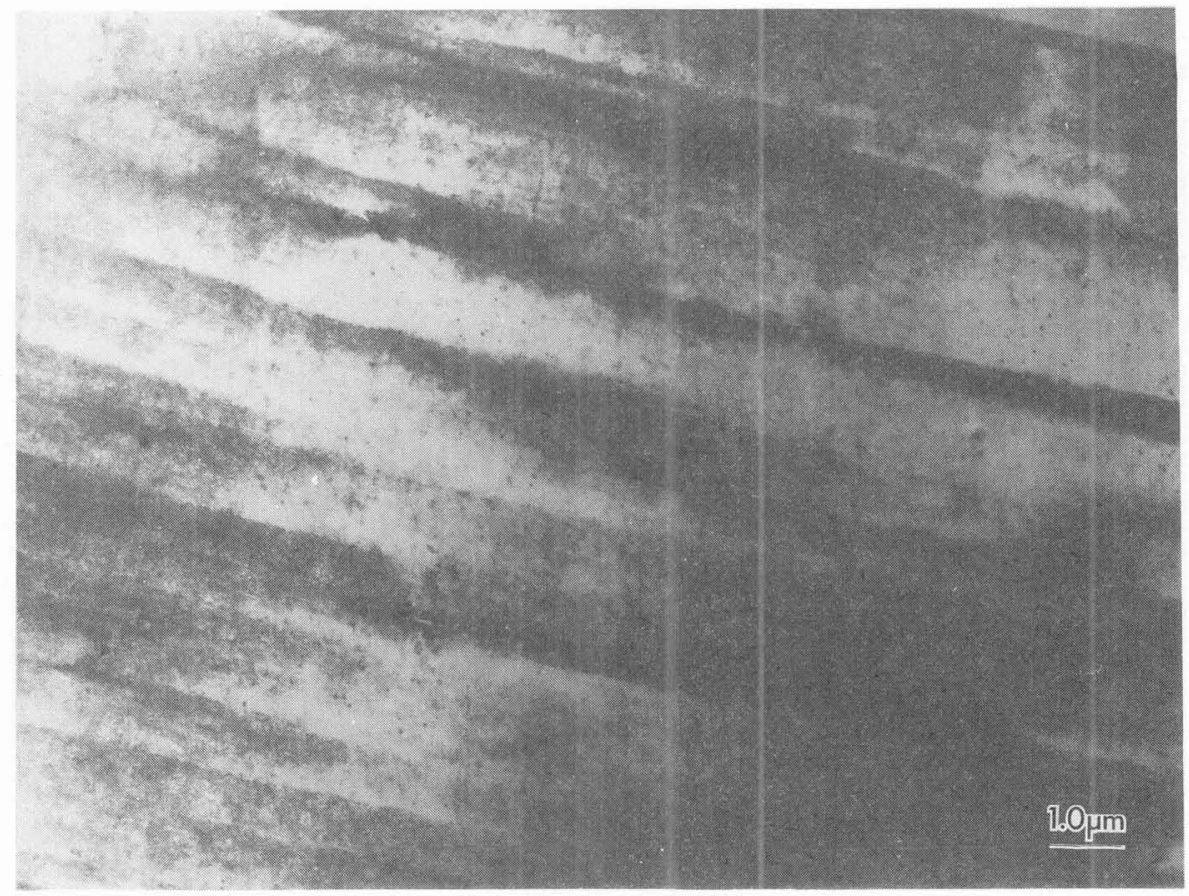

Figure 1. Transmission electron micrograph showing intense planar slip in deformed 8090 sheet with a fine recrystallised grain structure. Sample aged $12 \mathrm{~h}$ at $150 \mathrm{C}$ prior to straining.
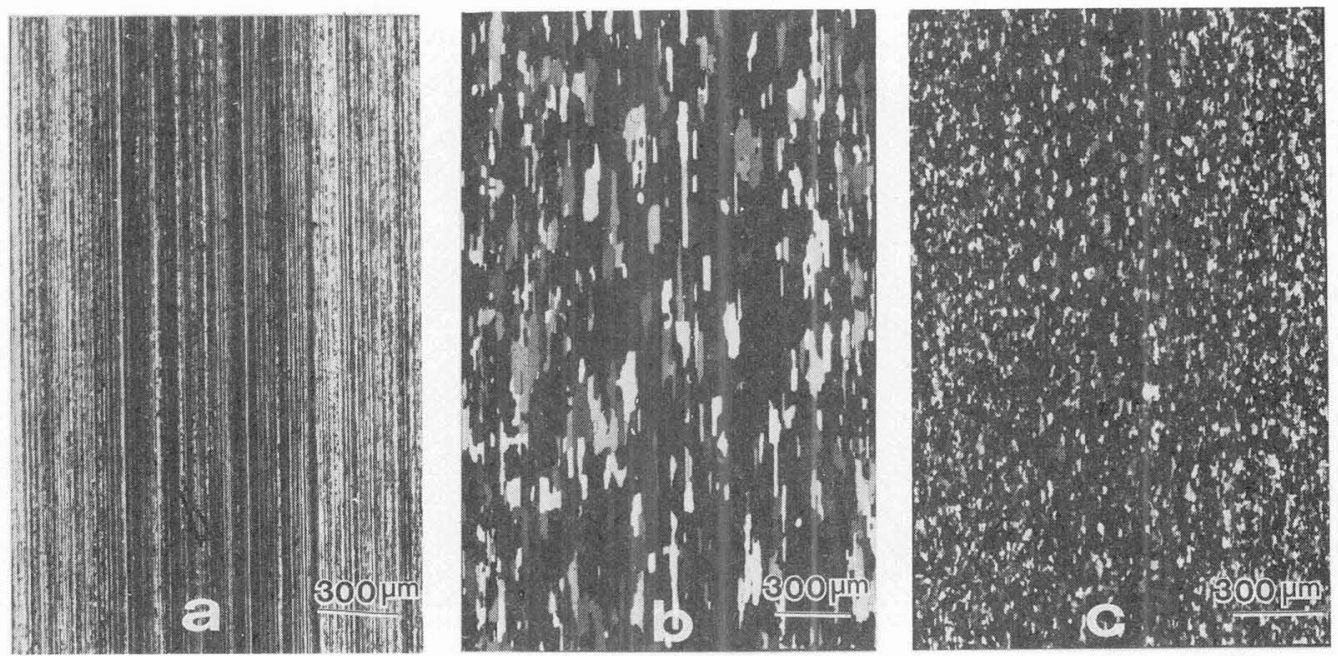

Figure 2. Optical micrographs showing the grain structures of the 8090 sheet samples used in the fracture toughness testing programme.

(a) unrecrystallised (b) laminar recrystallised and (c) fine grain recrystallised. 


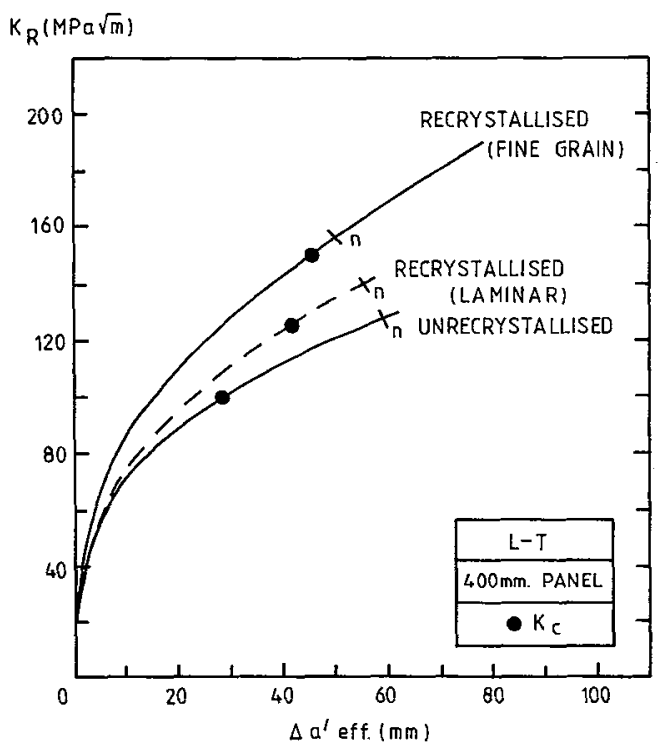

Figure 3. The effect of microstructure on the R-curves of 8090 sheet with an $0.2 \% \mathrm{PS}=340 \mathrm{MPa} . \mathrm{n}$ indicates the net section stress.

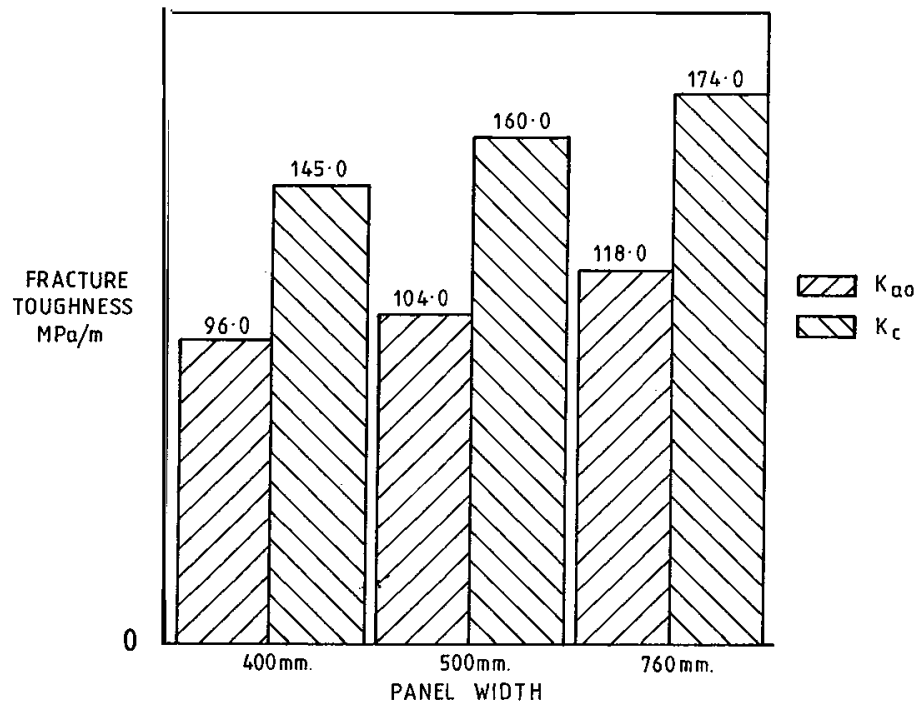

L-T ORIENTATION

Figure 4. The effect of panel width on the L-T fracture toughness of fine grain recrystallised 8090 sheet aged $12 \mathrm{~h}$ at $150 \mathrm{C}$. 2024- T3 has values of $\mathrm{Kc}$ and $\mathrm{KaO}$ of $203 \mathrm{MPa} / \mathrm{m}$ and $203 \mathrm{MPa} / \mathrm{m}$ respectively at a panel width of $760 \mathrm{~mm}$. 


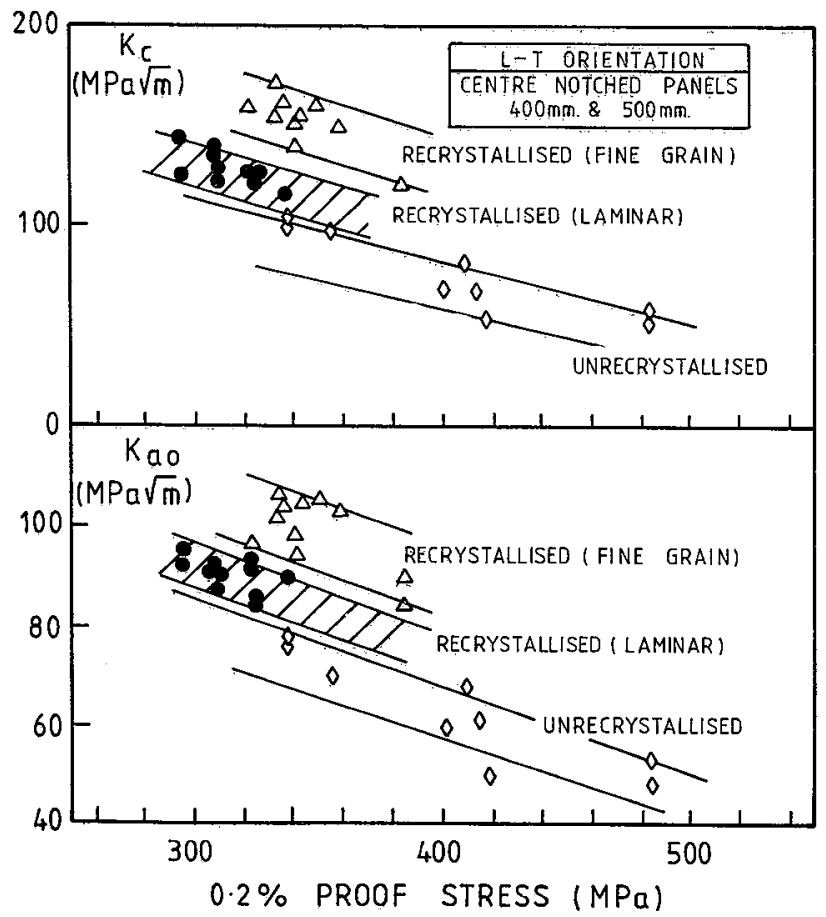

Figure 5. The influence of grain structure on the fracture toughness- proof stress relationship for 8090 sheet with different grain structures.

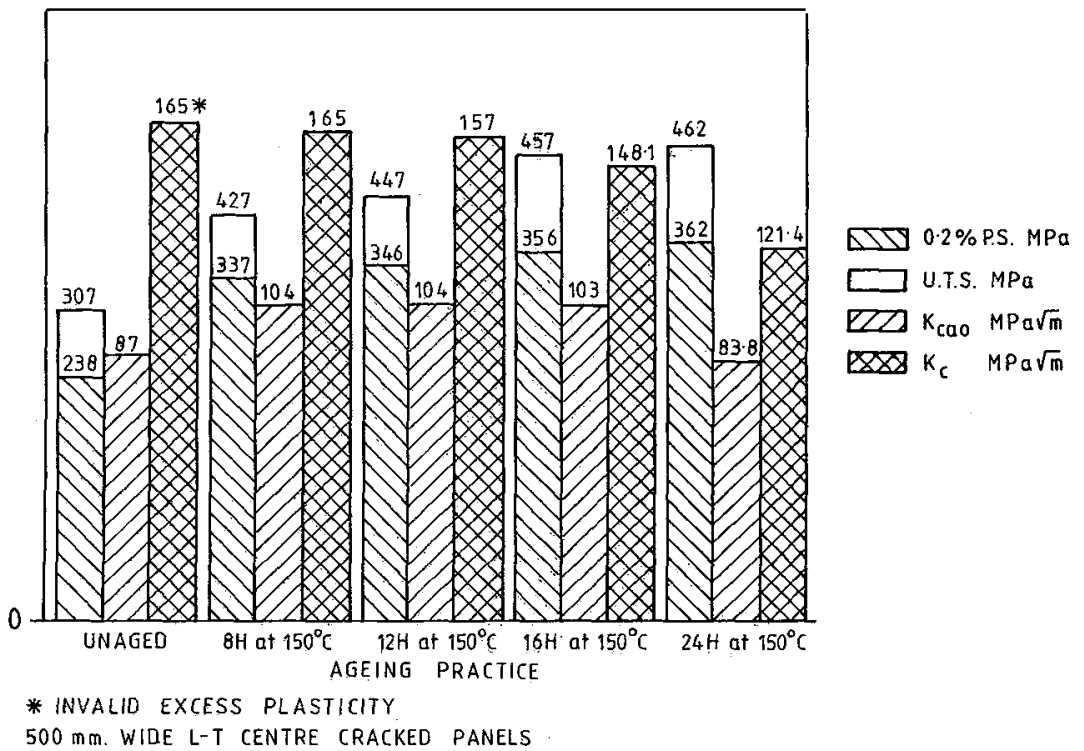

Figure 6. Variation in strength and fracture toughness with ageing time at $150 \mathrm{C}$ for fine grain recrystallised 8090 sheet. 
$T-L$

Fracture Toughness

$M P a \sqrt{m}$

Material Stretched $2 \%$

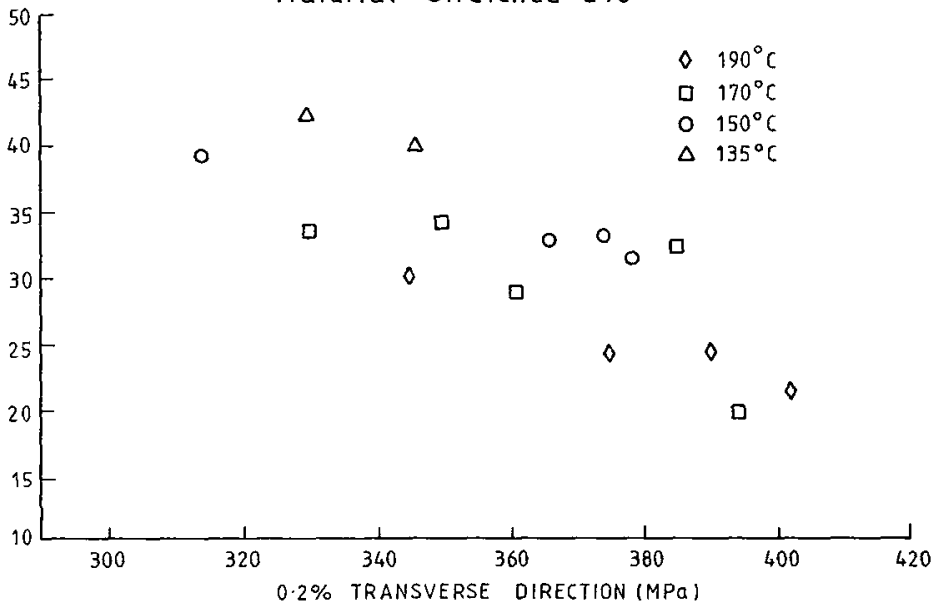

Figure 7. The influence of ageing temperature on the $T-L$ orientation strength and fracture toughness of $809025 \mathrm{~mm}$ plate stretched $2 \%$ prior to ageing.

$T-L$

Fracture Toughness

$\mathrm{MPa} \sqrt{\mathrm{m}}$

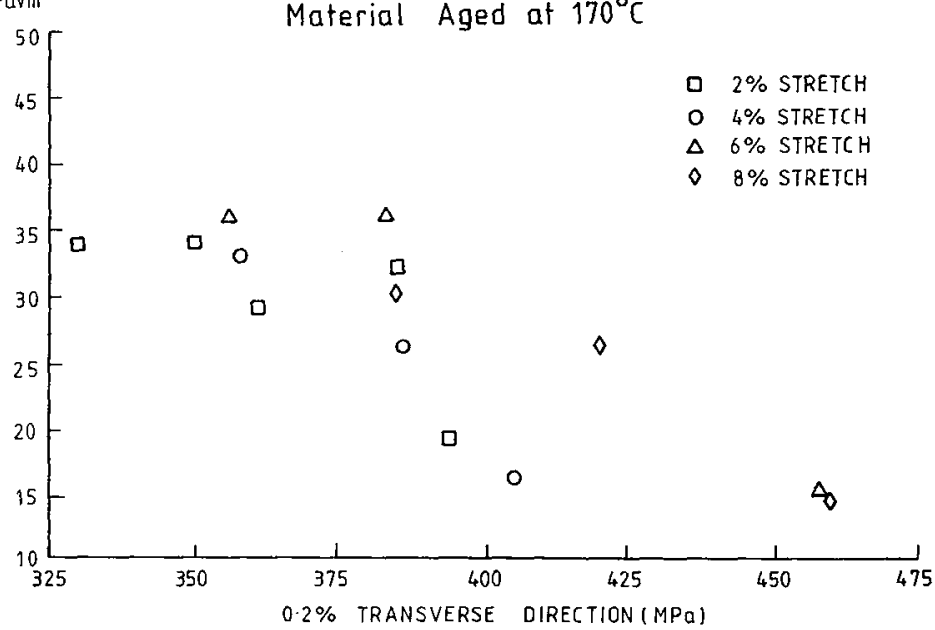

Figure 8. The influence of stretching prior to ageing on the $\mathrm{T}-\mathrm{L}$ orientation strength and fracture toughness of $809025 \mathrm{~mm}$ plate aged at $170 \mathrm{C}$. 


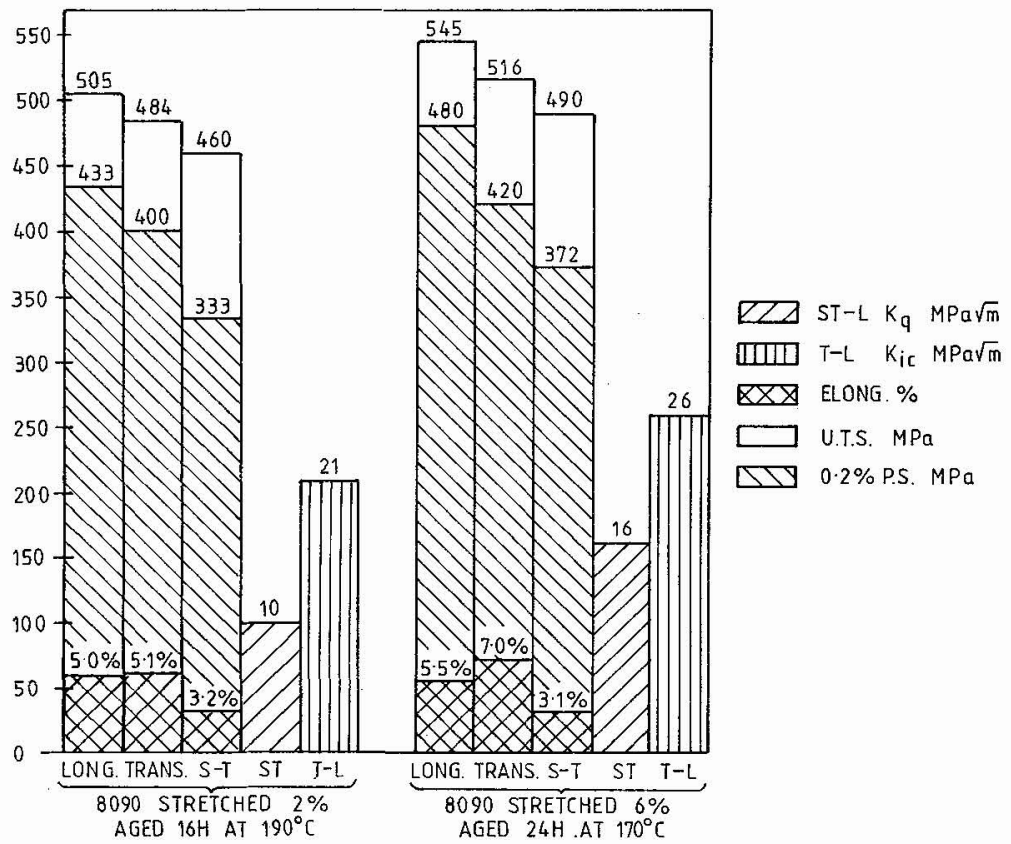

Figure 9. Comparison of the mechanical properties of $25 \mathrm{~mm} 8090$ plate given a FTMT treatment involving a $6 \%$ stretch and ageing $24 \mathrm{~h}$ at $170 \mathrm{C}$ with material stretched $2 \%$ and aged $16 \mathrm{~h}$ at $190 \mathrm{C}$.
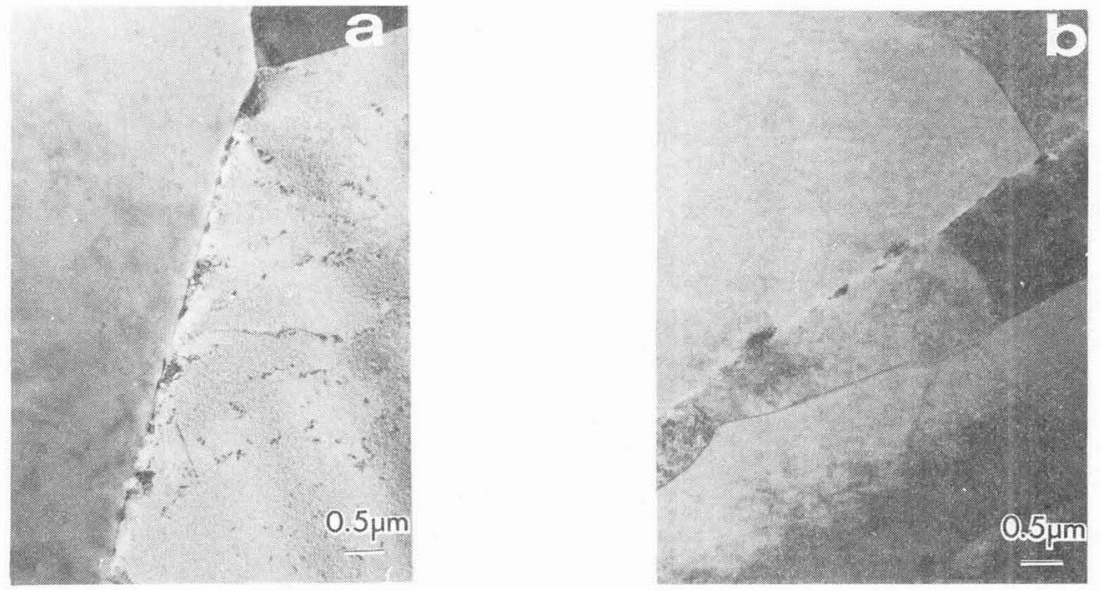

Figure 10. Transmission electron micrographs showing the change in grain boundary microstructure of 8091 plate with FTMT. (a) stretched $2 \%$ and aged $16 \mathrm{~h}$ at $190 \mathrm{C}$; (b) stretched $6 \%$ and aged $32 \mathrm{~h}$ at $170 \mathrm{C}$. 


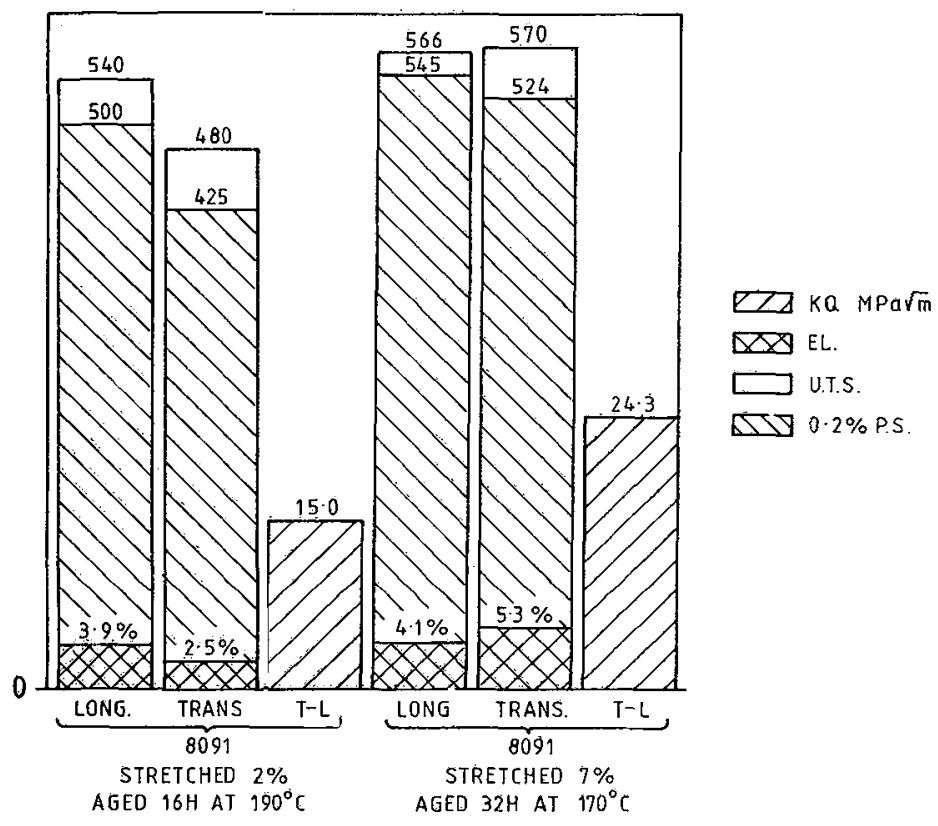

Figure 11. Comparison of the mechanical properties of $12.5 \mathrm{~mm} 8091$ plate (a) stretched $2 \%$ aged $16 \mathrm{~h}$ at $190 \mathrm{C}$; (b) stretched $6 \%$ aged $32 \mathrm{~h}$ at $170 \mathrm{C}$. 